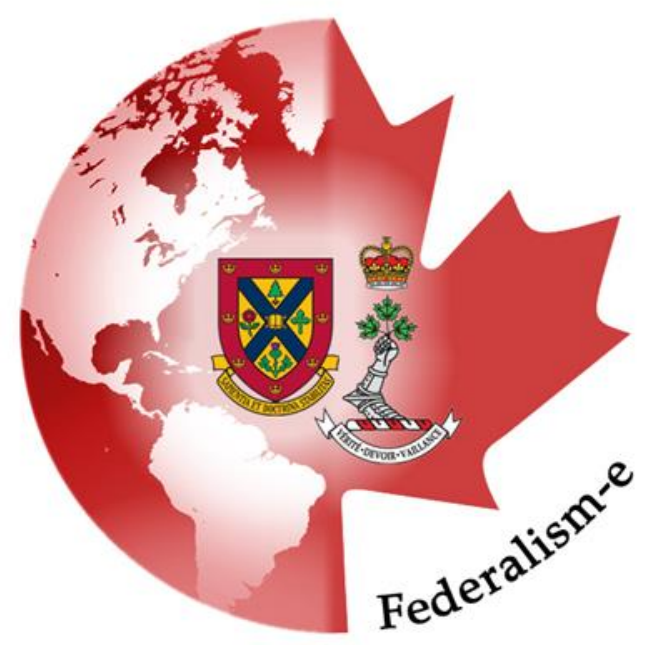

\title{
Canadian Federal Dynamics: \\ Intergovernmental Relations as the Future for Quebec
}

JENNA HERDMAN

Dalhousie University

Quebec's desire for recognition as "pas comme les autres" has defined fifty years of Canadian politics. In Canada, citizens have multiple layers of identity, including their dual allegiance to the federal nation and provincial culture. In the case of Quebec, these two identities often come into conflict with each other. Quebec nationalist sentiment which manifests itself through threats of sovereignty and demands for constitutional recognition, through negotiation with the federal government, has characterized the nature of Canadian federalism. Quebec has already been greatly accommodated and is privileged in the federal system in comparison to the other provinces. Moreover, the failure of the Liberal governments to create a pan-Canadian identity that Quebec accepts, as well as the Conservatives' failed attempts to modify the constitution, demonstrate the inability for constitutional reform to recognize Quebec as distinct throughout the past fifty years of Canadian federal relations. The door has therefore been left open for Quebec's question of distinctness to be resolved through intergovernmental relations/negotiations. Through such negotiation Quebec can develop and enhance its unique status at the inter-provincial level and thus further enhance its unique status in the federal system. In the last fifty years, the threat of Quebec secession and the pushes from Quebec for constitutional change have changed the face of federalism. These attempts, and their failures, have proven that the question of Quebec must be addressed through intergovernmental relations, instead of changing the actual structure of the federation through secession or constitutional reform. This essay will argue that the secession of Quebec would be a disastrous choice for both Quebec and Canada; Quebec's needs are already promoted within Canada, secession would undermine the attributes of federalism, and the independent government of Quebec would not protect minorities.

\section{A Distinct Province: The Case of Quebec}

To understand how Quebec should be accommodated within the Canadian federation, one must first understand why Quebec sees itself as being distinctly different from other provinces. The Quebecois are the largest language minority in Canada, and French Canadians comprise one of the 
two founding peoples of Canada. ${ }^{1}$ Some historians suggest that Quebec was responsible for Canada becoming a federation because while some political leaders, including Sir John A. MacDonald, would have preferred a unitary union, Quebec was insistent on becoming a federation. Most Canadian federalists interpret confederation as a multi-lateral agreement and union between multiple, equal provinces. In contrast, Quebec nationalists see Confederation as a pact between the two founding peoples, English Canada in its entirety and Quebec. Quebec therefore sees itself as a community with cultural uniqueness that begs protecting.

The Quiet Revolution of the 1960's, a period of rapid economic growth and increased solidarity, saw Quebec change from a rural, religious society in which the French were a minority within their own province, to one of the most secular provinces in Canada. The Quebecois migrated from the countryside to an urban economic setting and French became the official language of business in Quebec. ${ }^{2}$ The Quiet Revolution led to the Quebecois becoming a powerful majority in the province, and created a "deeply felt desire to protect and advance nationalism, language, and civilization of French Canada". ${ }^{3}$ In the 1970s, there was the emergence of the Parti Quebecois (PQ), a provincial ruling party, and the Bloc Quebecois (BQ), a federal party whose candidates ran solely in Quebec. The BQs candidates ran for Parliament with the goal of Quebec eventually seceding from that Parliament; ${ }^{4}$ Trudeau warned Quebecers that "a vote for the $\mathrm{BQ}$ was a vote for sovereignty". ${ }^{5}$ Indeed, this period resulted in the aggregation of Quebec interest and brought to the forefront of federal discourse the issue of Quebec

\footnotetext{
1 J Smith, Federalism, (Vancouver: UBC Press) 2004.

2 R Gibbons, "Constitutional Politics," Canadian Politics (2009): 103-110.

3 Hugh Segal, "A Federalist Perspective," Orbis 41(1997): 461.

4 Doshi Sameer, “Quebec's Lesson," Harvard International Review 21 (1999): 19.

${ }^{5}$ Thomas Courchene, "The changing nature of Quebec-Canada relations: From the 1980 referendum to the summit of the Canadas," IRPP Working Paper (2004).
}

distinctness. With the nationalist sentiment of the Quebecois, their control of the province and the $P Q$ and $\mathrm{BQ}$ promoting independence, the idea of Quebec secession became paramount to Canadian federal dynamics.

The idea of Quebec's secession from Canada was promoted as a vision of continued economic association with Canada, but with the Quebecois as "maîtres chez nous," and thus with complete legislative jurisdiction over their province. ${ }^{6}$ Many extreme nationalists in Quebec fought to promote this vision. Although English Canada opposed this vision, the emergence of Quebec as a national player in Canada identified the need for some sort of reform of the federal system. ${ }^{7}$ Hence, for twenty years and through two referendums, Quebec used the threat of secession to force Canada to try and meet Quebec's demands.

\section{Exploring Secession: Quebec's Place in the Canadian Federation}

Quebec does not require secession to support its status and achieve a reasonable degree of self-determination. Although a minority in a federation should be able to liberate themselves from a regime with which they do not identify, the federation of Canada already allows adequate decentralization of authority, distributive and legislative power to the provinces to accommodate Quebec. $^{8}$ Sameer argues that minorities plagued by tyrannical regimes with different languages and opposing ancestries should fight for secession to win "recognition, liberty, and political autonomy." Quebec, however, shares ancestry and a long tradition of negotiating with English Canada. Moreover, Canadian federalism has a method by which Quebec can aggregate its interest through

\footnotetext{
${ }^{6}$ P Oliver, "Canada's Two Solitudes:

Constitutional and International Law in Reference re Secession of Quebec," International Journal on Minority \& Group Rights 1 (1999): 65-95.

${ }^{7}$ Gibbons, "Constitutional Politics," 103-110.

${ }^{8}$ Hilliard Aronovitch, "Seceding the Canadian Way," Publius: The Journal of Federalism 4 (2006): 541-564.
} 
intergovernmental relations, which places Quebec in a stronger position as a member of the federation than as a unitary state. This view is supported by historical Quebec leader and Canadian Prime Minister Sir Wilfred Laurier, who argued that Quebec's uniqueness is better preserved within Canada than "adrift in the homogenizing, anti-bilingual melting pot of America." ${ }^{9}$ Furthermore, Quebec has embraced "le virage vers les marchés," and Courchene argues that acceptance of this market-oriented perspective demonstrates that Quebec can be much more economically successful as part of a great federation as opposed to a tiny nation alongside the larger countries of the US and Canada.

In the 1980s, Prime Minister Trudeau attempted to create a pan-Canadian identity and accommodate minorities. During the threat of secession, Trudeau fought to create a new nation from the ground up of a unified Canada with a strong central government that could hold it together. Quebecers desired the supremacy and protection of the French language; accordingly, Pierre Trudeau promoted the rights of French Canadians both in and out of Quebec with the Official Languages Act, making French one of Canada's two official languages, effectively protecting it. ${ }^{10}$

Currently, Quebec possesses more unique responsibilities and power than any other province, but continually makes increasing demands and threats to the system. ${ }^{11}$ For example, it receives different qualifications for Senators, a special role in immigration, and powers beyond those of other provinces. Quebec has effectively used the threat of sovereignty and claim to distinctiveness to gain unique administrative powers, such as in the arenas of taxation, pensions and immigration. ${ }^{12}$ It is fighting to establish itself as a province that is not only "pas comme les autres," but more powerful than its formerly equal counterparts in the federation. Quebec has therefore already achieved a distinct status in Canada, both through the spread of the French language and its special powers.

\footnotetext{
${ }^{9}$ Segal, “A Federalist Perspective," 461.

${ }^{10}$ Oliver, "Canada's Two Solitudes," 65-95.

${ }^{11}$ Smith, Federalism.

12 Oliver, "Canada's Two Solitudes," 65-95
}

Not only does Quebec stand to lose by secession, but the loss of Quebec would also undermine federalism, for multiple reasons. To begin, secession would result in a massive upheaval of Canadian society. ${ }^{13}$ Quebec is not being deprived of important rights; on the contrary, it has even greater appointed responsibilities than any other province. Therefore, it should not separate merely to become 'masters in their own house' at the expense of the federation. ${ }^{14}$ Secession is not only unnecessary, but the consequences would also be very dire for Canadian federalism. Quebec's secession would set a precedent for the rest of Canada, since, if a founding province can fight to separate then so too could other provinces. To have the ability to secede might increase the risks of struggle between groups and discourage compromise in government. $^{15}$ Furthermore, Canada is a model for federal systems around the world. Having a founding member separate would undermine Canada's legitimacy in the international community. ${ }^{16}$ Canada is an international model for other countries pursuing federalism, and Oliver argues that failings in Canada's federal system, such as a distinct, founding province separating, would "deprive other nations of a long-standing example of the attempt to accommodate difference." Furthermore, Canada's diversity is ensured by the intergovernmental cooperation between the federal government and provincial governments, giving a voice to a variety of identities. A single government in a secular Quebec would not be able to accommodate minorities.

\section{Minority Protection}

Although Quebec argues that it is a marginalized minority in the federation of Canada, a crucial role of federalism is to preserve the diversity of its many components. Disadvantaging minority groups within Quebec itself would be another consequence of secession. Separatists presumably assume that Quebec's current borders are unquestionable, without consideration for aboriginal territories in

\footnotetext{
${ }^{13}$ Aronovitch, "Seceding the Canadian Way," 541-564.

14 Ibid.

15 Ibid.

${ }^{16}$ Ibid.
} 
northern Quebec. ${ }^{17}$ Despite Quebec's complaint of being a marginalized minority in Canada, Oliver argues that "recognition guaranteed to one national group should not be denied to smaller groups within," 18 and secession would force Quebec's own minorities of Anglophones, aboriginals and others to uproot their lives and decide whether they wish to belong to the new sovereign state of Quebec.

Aboriginals arguably have a role in Canada that is as distinct as that of Quebec: there is even an argument that aboriginals are one of three, instead of two, founding nations of Canada. ${ }^{19}$ Aboriginals with land claims in Quebec might believe that it is advantageous to leave Quebec and stay within the Canadian federation. In fact, a referendum of native people in Quebec showed that $97 \%$ refused to "be transferred along with their land from Canada into an independent Quebec." ${ }^{20}$ Areas of Quebec, such as Montreal, also have a prominent Anglophone population. An example of how Anglophones might be disadvantaged in a homogeneous Quebec involves the French Language Charter, which requires that the French letters on store signs be twice as high as the English, and therefore upset merchants in predominantly Anglophone regions. ${ }^{21}$ Similar or more extreme measures might further alienate Anglophone or other minorities. The precedent that Quebec has set in disregarding minority interests is of concern. Since one constitutional responsibility of the federal state is to protect minorities, secession is unconstitutional because it would be a threat to minorities within Quebec. Therefore, Quebec's separation from Canada would lead to negative consequences for those groups that are not part of the Quebecois majority and whose interests are currently represented by the federal government.

\section{Attempting to Solve the Quebec Question: Intergovernmental cooperation?}

\footnotetext{
${ }^{17}$ Aronovitch, "Seceding the Canadian Way," 541-564.

18 Oliver, "Canada's Two Solitudes," 65-95.

${ }^{19}$ Oliver, "Canada's Two Solitudes," 65-95

${ }^{20}$ Aronovitch, "Seceding the Canadian Way," 541-564.

${ }^{21}$ Sameer, “Quebec's Lesson, " 19.
}

Quebec has survived two referendums without undergoing secession, however its demand for constitutional recognition has also shaped the past generation of politics. In 1982, Quebec was insulted that the Constitution Act was virtually silent on the issue of Quebec's distinctiveness. Furthermore, Quebec was incensed that the addition of the Charter of Rights and Freedoms and the new amending formula was done without obtaining the consent of the province of Quebec. ${ }^{22}$ Quebec essentially seeks constitutional recognition that would make it distinct from the other provinces but in the Constitution Act, Quebec is a province "like all others." ${ }^{23}$ This demand for distinctiveness and special status in the constitution is both symbolic, reflecting a desire for recognition, and legislative, as some wish to expand Quebec's duties and provincial responsibilities beyond those delegated by the current constitution. ${ }^{24}$ However, it is notable that in recent years Quebec's demands for more responsibilities have evolved into asking for more funding from the federal government to better apply its current constitutionally appointed powers. $^{25}$

Different federal governments have attempted to reconcile Quebec within the federal fabric; however, all such attempts have failed to reconcile Quebec and thus demonstrate that constitutional reform solely on the issue of Quebec is futile. Segal explains that Liberal governments have tended to develop "centralist solutions, such as national bilingual rules." Trudeau emphasized Canada's status as a bilingual nation and the equality of French and English outside the borders of Quebec. ${ }^{26}$ Trudeau's goal was to ensure that Francophone Quebecers had opportunities beyond the boundaries of their province, and, accordingly, that Francophone Canadians across the country felt properly represented at the federal level of government. ${ }^{27}$ However, this accommodation at the federal level was not enough for strong nationalists in Quebec.

\footnotetext{
${ }^{22}$ Oliver, "Canada's Two Solitudes," 65-95

${ }^{23}$ Gibbons, "Constitutional Politics," 103-110.

${ }^{24}$ Smith, Federalism.

${ }^{25}$ Courchene, "The changing nature of QuebecCanada relations."

${ }^{26}$ Oliver, "Canada's Two Solitudes," 65-95

27 Ibid.
} 
Trudeau's contemporary René Lévesque, founder of the $P Q$, focused on the state of French within Quebec instead of its status within the rest of Canada. ${ }^{28}$ Lévesque's focus on French solely within Quebec demonstrates the $P Q$ 's lack of willingness to cooperate with the rest of the provinces, and an increased need for communication and collaboration with the rest of Canada. After the triumph of federalism in the 1995 failed Quebec referendum on seceding, the federal Liberal government rushed legislation through Parliament to recognize Quebec by "lending Parliament's veto to Quebec" so that Parliament couldn't pursue amendments without Quebec's support. However, the actual constitution was left unchanged, providing further ammunition for Quebec's insistence on constitutional reform. ${ }^{29}$

In contrast to the Liberal governments' approach of attempting to bring Quebec closer to the rest of Canada by acknowledging the special status of French, Conservative governments have attempted to accommodate Quebec by changing the constitution. $^{30}$ Conservatives led by PM Brian Mulroney sought to renegotiate the constitution and decentralize the federation to aid Quebec in having a special status. ${ }^{31}$ The Meech Lake Accord of 1987 was seen as the "Quebec Round," of the constitutional debate, designed to formally address Quebec's concerns. Conditions concerning Quebec included: "constitutional recognition of Quebec as a distinct society, a greater role for Quebec in immigration, a provincial role in appointments to the Supreme Court of Canada, and the return of Quebec's traditional veto over constitutional amendments." ${ }^{32}$ The Accord was rejected by two provinces, and Quebec saw this as a further sign of Canada's rejection of Quebecois society's uniqueness. ${ }^{33}$ One reason for nonQuebecers to reject the Accord was the idea that Quebec having a special status in a federation where all provinces were equal is in fact unconstitutional. ${ }^{34}$

\footnotetext{
28 Ibid.

${ }^{29}$ Gibbons, "Constitutional Politics," 103-110.

${ }^{30}$ Segal, "A Federalist Perspective," 461.

${ }^{31}$ Oliver, "Canada's Two Solitudes," 65-95

32 Ibid.

33 Ibid.

${ }^{34}$ Courchene, "The changing nature of QuebecCanada relations."
}

Another criticism of Meech Lake was that it did not address the needs of other groups or minorities in Canada. The subsequent Charlottetown Accord was the "Canada Round," to which the other provinces and other groups brought their demands. Charlottetown's agenda was therefore spread too thin, as everyone's needs were mentioned but nobody was entirely satisfied. ${ }^{35}$ After the 1995 referendum, in which Quebec sovereignty was once again shut down, Quebec relaxed on the fight for a distinctive status via secession or constitutional reform. Nevertheless, Quebec nationhood is still essentially all about disallowing the federal government to "regulate, legislate, or dictate in areas of Quebec's constitutional jurisdiction," as was done in the 1982 Constitution Act. $^{36}$ Furthermore, significant differences between Quebec and the rest of Canada are still prevalent. A symbol of this divide and Quebec's disassociation with Canada was the absence of the Canadian flag at the Quebec National Assembly in September 2012.

It is mandatory that the issue of Quebec's distinctiveness is addressed in order to bring attention to other issues confronting Canadian federalism. However, this must be addressed not through threats of secession or constitutional change, but by negotiation between the Quebec government, the federal government, and the other provincial governments. "Referendum fatigue" reflects that Canadians are weary of the Quebec debate that has dominated Canadian discourse for decades. Gibbons explains how now that Quebec has calmed down, other issues have been added to the federal agenda such as prosperity in the West, under-representation of the Western provinces in Parliament, and the needs of aboriginal peoples -- previously these groups could only bring attention to their problems within the context of a crisis with Quebec. ${ }^{37}$

Both secession attempts and constitutional change have been dangerous to the fabric of the country and thus unfeasible as solutions to the perceived problems. Therefore, intergovernmental

\footnotetext{
${ }^{35}$ Oliver, "Canada's Two Solitudes," 65-95

36 Courchene, "The changing nature of Quebec-Canada relations."

${ }^{37}$ Gibbons, "Constitutional Politics," 103-110.
} 
relations, which are the negotiation between provinces and levels of government, are the best way to satisfy Quebec's demands for a distinct identity within Canadian federalism. The Calgary declaration involved the nine premiers outside of Quebec meeting to consider a non-constitutional recognition of Quebec as distinct within the provincial sphere, and this negotiation, though it does not entail changing the structure of Canada, is the most effective way to elicit change. ${ }^{38}$ Courchene also argues that provinces have the ability to achieve the powers of a sovereign state and establish themselves on an international market within the context of the federation. ${ }^{39}$ To preserve itself, Quebec needs to be satisfied to be a unique province within the Canadian federation. Its inclusive powers allow it to have a greater jurisdiction over its own people as well as a distinct identity within Canada. However, Quebec should be satisfied to negotiate the terms of its distinct status with the other governments.

Further evidence of steps taken to use intergovernmental relations instead of secession or constitutional reform to accommodate Quebec was the 2000 Clarity Act. The Clarity Act legislates that Quebec cannot unilaterally choose to separate from Canada. However, if a clear majority of Quebecois vote for secession, the rest of Canada is required to negotiate the terms of Quebec's sovereignty. ${ }^{40}$ This legislation demonstrates a shift towards intergovernmental cooperation, and level of agreement within Canada which was not present in the Meech Lake or Charlottetown Accords. The implementation of the Council of the Federation, which Courchene describes as an "overarching institution embodying pan-Canadian values," is the coordination between the provincial governments to promote their interests and present a united front against the federal government. Quebec has been granted a special status in this union between provinces; for example, Quebec has the option to opt out of the Pharmacare Plan. ${ }^{41}$ This demonstrates the other provincial governments' desire to work with Quebec and to recognize its distinct status as a historical founding nation and a culturally different province within the federation.

\section{Conclusion}

This paper has shown that the debates surrounding Quebec's status as a distinct nation have highlighted the importance of using intergovernmental relations instead of threats of secession and demands for constitutional reform to work within the federal system. It has been argued here that secession is not a valid goal for a variety of reasons -- it is not actually necessary for Quebec to achieve and maintain its language and culture, it contradicts the constitution, and it would threaten the welfare of minorities within Quebec. The era of executive federalism saw governments try to appease Quebec with attempts to manipulate the constitution to recognize Quebec's distinctiveness. This was addressed by attempting to integrate Quebec into a unified Canada, and alternatively creating Accords with the aim of modifying the constitution. Quebec's threats have been quelled for the time being, but divisions between French Canada and the rest of Canada continue. These failures are sufficient evidence in support of the view that the future course of action for resolving the divide between Quebec and the rest of Canada lies in intergovernmental relations and in the establishment of relationships that value accommodation and equality among the components of the federal system. As Quebec seeks to protect its status as "pas comme les autres," it will be able to negotiate its distinctness in conjunction with the rest of Canada.

\footnotetext{
${ }^{38}$ Gibbons, "Constitutional Politics," 103-110.

${ }^{39}$ Courchene, "The changing nature of QuebecCanada relations."

${ }^{40} \mathrm{Ibid}$.

${ }^{41}$ Ibid.
} 


\section{Bibliography}

Aronovitch, Hilliard. "Seceding the Canadian Way." Publius: The Journal of Federalism. no. 4, 2006, 541-564.

Courchene, Thomas J. "The changing nature of Quebec-Canada relations: From the 1980 referendum to the summit of the Canadas." IRPP Working Paper. 2004-08, 2004.

Gibbons, R. "Constitutional Politics." Canadian Politics. 103-110, 2009.

Sameer, Doshi. "Quebec's Lesson." Harvard International Review, 21, no. 3: 18, 1999.

Segal, Hugh. "A Federalist Perspective." Orbis, 41, no. 3: 461, 1997.

Smith, J. Federalism. Vancouver: UBC Press, 2004.

Oliver, P. "Canada's Two Solitudes: Constitutional and International Law in Reference re Secession of Quebec." International Journal on Minority \& Group Rights, no. 1/2, 65-95, 1999. 